\title{
TRAFFIC MANAGEMENT IN JEMBER DISTRICT PAGAH AREA
}

\author{
Della Dwi Nuariningsih ${ }^{1}$, Achmad Wicaksono ${ }^{2}$, Ludfi Djakfar ${ }^{3}$ \\ ${ }^{1,2,3}$ Department of Civil Engineering, Brawijaya University, Malang, East Java, Indonesia \\ Correspondence: delladewinni@gmail.com
}

\begin{abstract}
Pagah district is one of the urban areas which has several intersections that support community activities. Therefore, the existing public facilities in this area must support community activities. One of them is to ensure the performance of the intersections in the Pagah area is still in good condition. From secondary data obtained from Jember Regency in 2019 Figures, it shows that the vehicle growth rate in Jember Regency has increased over the last 5 years. The results of the analysis with reference to the Indonesian Road Performance Manual show that the existing performance conditions of intersections in the Pagah district indicate that the delay value at the intersections does not meet the requirements. The methods taken in this study to overcome the existing problems are optimizing the intersection cycle time at the Pagah district.
\end{abstract}

Keywords : evaluation,performance, signalized intersection, delayed, cycle time, green time

\section{INTRODUCTION}

Today transportation has become an important necessity for many people. The smoothness of transportation in an area around of city will facilitate the movement of both people and goods. However, if on the other hand transportation does not go well, then it will have a big impact on human activities every day. Like traffic jams that interfere with people's mobility. Traffic problems in developing districts such as in Jember Regency cannot only be done by adding road infrastructure, this is due to the limited land available. So it is necessary to have traffic management to solve these traffic problems. An important traffic management strategy to be implemented to solve the problem of urban and developing district transportation is by implementing the installation and arrangement of Traffic Signaling Devices (APILLs) at intersections. Appropriate APILL application at intersections will smooth the flow, thereby reducing delays and queues.

Jember Regency is one of the developing districts in East Java with a population of 2,858,142 people (BPS, 2018)[1]. Jember Regency is also one of the developing areas which certainly has traffic problems whose symptoms need to be considered and handled appropriately. Improper application of traffic management will certainly cause problems. In this study, the new cycle time planning still takes into account the coordination theory and formulation of MKJI, 1997.

The development in the area around the Pagah area is quite rapid due to being close to the city center, being in a campus environment that has the potential to have a rapid population growth rate due to new student admissions every year, besides that the two intersections are close to the school area, shopping area, and office area. In addition, the growth in the number of vehicles in Jember Regency has increased every year, as shown in Figure 1. 


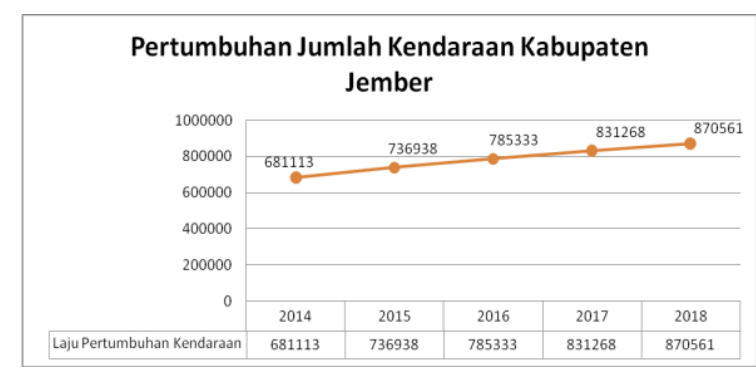

Figure 1. Growth in the Number of Vehicles

\section{STUDY METHODOLOGY}

The Spada intersection, the Bhayangkara intersection, and the Jarwo intersection are intersections on the arterial road and the collector road. The Jarwo intersection and the Mastrip intersection are located near the University of Jember which are one of the main accesses for students to do activities and has an important role in the activities of the surrounding community. The Jarwo intersection is a signaled intersection with three approaching arms and is on the national road connecting Jember Regency and Bondowoso Regency. While the Mastrip intersection is a signaled intersection with four approaching arms. The two intersections are roads in two directions and have 2 lanes without a median. The Mastrip intersection itself is an important node, because the intersection is a connecting route from the Tegalboto area and from Bondowoso Regency to the urban area of Jember Regency.

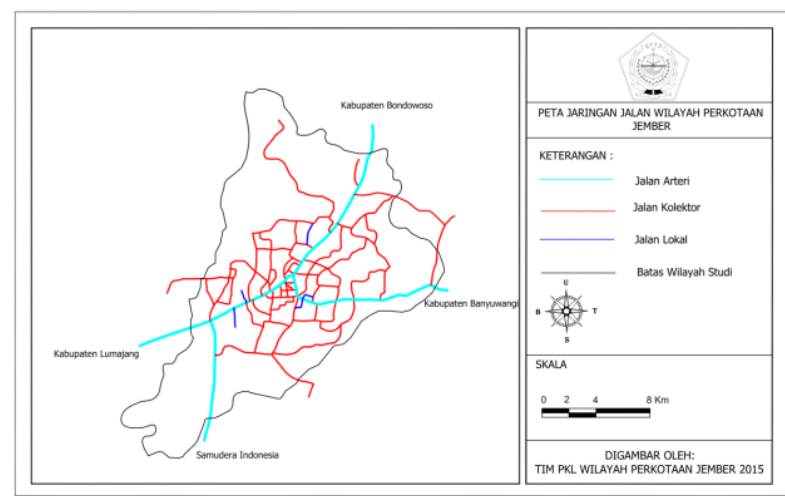

Figure 2. Urban Area Road Network Map for Jember Regency

From the Picture 2 shows that the location of this study is on the arterial road and the collector road.

\subsection{Intersection Performance Analysis}

In calculating intersection performance, the important elements are traffic lights, capacity, and service levels. So that the intersection performance can run well, the capacity and level of service need to be considered in evaluating the operation of the intersection with traffic lights. The benchmarks of the intersection performance are based on the long queues, the number of stopped vehicles, and delays. As for the benchmark of the quality of intersection performance is to use the following variables (Ministry of Public Works, 1997)[2] :

\section{Capacity}

Capacity is the maximum traffic flow that can be maintained on a part of the road under certain conditions. Usually expressed in units of pcu / hour. The total capacity for all intersection arms is the result of the confusion between the basic capacity ( $\mathrm{C} 0$ ), namely the capacity under ideal conditions and the adjustment factors $(\mathrm{F})$, taking into account the effect of field conditions on capacity, with the equation:

$$
C=\operatorname{Cox}_{W} x F_{M} x F_{C S} x F_{R S U} x F_{L T} x F_{R T} x F_{M I}
$$

\section{Delay}

The delay at the intersection is calculated by the formula:

*) for the degree of saturation $<1,0$ : $D G=(1-D S) x(P T x 6+(1-P T) x 3)+D S x 4($ det/smp $)(2)$

*) for the degree of saturation> 1,0 :

$$
D G=4
$$

\section{Intersection Service Level}

The intersection service level is a measure of the quality of traffic conditions that are acceptable to road users. If the traffic volume increases, the service level decreases, a result of the traffic flow which is the worst in terms of service characteristics. The relationship between delay and service level is shown in Table $\mathbf{1}$ as a reference for the assessment of intersections: 
Table 1. Signalized Intersection Service Level Criteria

\begin{tabular}{cc}
\hline $\begin{array}{c}\text { Delay per } \\
\text { Vehicle } \\
\text { (seconds / Veh) }\end{array}$ & $\begin{array}{c}\text { Level of } \\
\text { Service }\end{array}$ \\
\hline$<5$ & $\mathrm{~A}$ \\
\hline $5,1-15$ & $\mathrm{~B}$ \\
\hline $15,1-25$ & $\mathrm{C}$ \\
\hline $25,1-40$ & $\mathrm{D}$ \\
\hline $40,1-60$ & $\mathrm{E}$ \\
\hline$>60$ & $\mathrm{~F}$ \\
\hline
\end{tabular}

\subsection{Optimum Cycle Tme (Co)}

The time interval between the lights of the green signal in a phase with the next green flame in the same phase is the cycle time. To calculate the optimum cycle time, the following equation is used:

$$
\text { Copt }=\frac{1,5 \times \mathrm{LTI}+5}{1-\mathrm{IFR}}
$$

information:

$$
\begin{array}{ll}
\text { Copt } & \text { : Optimum Cycle Time } \\
\text { LTI } & \text { : The amount of time lost per cycle } \\
\text { IFR } & : \text { Intersection Current Ratio }
\end{array}
$$

\section{ANALISYS AND DISCUSSIONS}

\subsection{Signalized Intersection Performance}

Optimization of traffic circulation is needed for the smooth running of the Pagah Area. It is developed using the method of setting up signaled intersections which are mutually coordinated with each other. Generally signal coordination is carried out on axle roads only, whereas on sections it is not required. This causes road users in the direction applied by the coordination system to experience greater delays .

The calculation of the existing conditions and optimum time conditions refers to the Indonesian Road Capacity Manual, 1997.The results of the calculations obtained are described in Table 3 .

In this study, the segment performance was also calculated in the existing conditions. The calculation results will be explained in Table 4 .

\subsection{Cycle Time Optimization}

Based on the results of the analysis of the existing intersection conditions, it is necessary to make improvements in order to obtain a better intersection condition than the existing condition.
Table 3 . Recapitulation of Signalized Intersection Performance Calculation Results

\begin{tabular}{cccc}
\hline \multirow{2}{*}{$\begin{array}{c}\text { Simpang } \\
\text { name }\end{array}$} & $\begin{array}{c}\text { Time } \\
\text { Period }\end{array}$ & $\begin{array}{c}\text { Existing } \\
\text { Intersection } \\
\text { Delay } \\
\text { (sec / pcu })\end{array}$ & LOS \\
\hline \multirow{2}{*}{$\begin{array}{c}\text { Spada } \\
\text { intersection }\end{array}$} & Morning & 364.51 & $\mathrm{~F}$ \\
\cline { 2 - 4 } & Noon & 150.05 & $\mathrm{~F}$ \\
\cline { 2 - 4 } Intersection \\
Bhayangkara & Average & 46.14 & $\mathrm{E}$ \\
\cline { 2 - 4 } & Morning & 17.20 & $\mathrm{C}$ \\
\cline { 2 - 4 } Jarwo & Average & 306.37 & $\mathrm{~F}$ \\
\cline { 2 - 4 } intersection & Morning & 5940 & $\mathrm{~B}$ \\
\cline { 2 - 4 } & Noon & 424.72 & $\mathrm{~F}$ \\
\hline \multirow{2}{*}{$\begin{array}{c}\text { Mastrip } \\
\text { intersection }\end{array}$} & Morning & 39.57 & $\mathrm{D}$ \\
\cline { 2 - 4 } & Noon & 58.52 & $\mathrm{E}$ \\
\cline { 2 - 4 } & Average & 60.05 & $\mathrm{~F}$ \\
\hline
\end{tabular}

Table 4. Result of Calculation of Existing Condition of Section

\begin{tabular}{cccccccc}
\hline Roads & $\begin{array}{c}\text { Time } \\
\text { Period }\end{array}$ & $\begin{array}{c}\text { Q } \\
(\mathrm{pcu} / \\
\text { hour })\end{array}$ & $\begin{array}{c}\text { C } \\
(\mathrm{pcu} / \\
\text { hour })\end{array}$ & DS & $\begin{array}{c}\text { FV } \\
\text { (veh / } \\
\text { hour) }\end{array}$ & $\begin{array}{c}\text { VLV } \\
\text { (veh / } \\
\text { hour) }\end{array}$ & $\begin{array}{c}\text { Travel } \\
\text { Time } \\
\text { (hour) }\end{array}$ \\
\hline 1 & 2 & 3 & 4 & 5 & 6 & 7 & 9 \\
\hline Mastrip & Morning & 1411 & 1939,494 & 0.73 & 36,708 & 24 & 0.0083 \\
\cline { 2 - 8 } Section & Noon & 1639 & 2260,072 & 0.73 & 33,649 & 23 & 0.0087 \\
\hline $\begin{array}{c}\text { Segment } \\
\text { PB. Sudirman }\end{array}$ & Morning & 3 & 4 & 5 & 6 & 7 & 0.0056 \\
\cline { 2 - 8 } $\begin{array}{c}\text { Segment } \\
\text { PB. Sudirman }\end{array}$ & Morning & 2026 & 6248,648 & 0.32 & 57.57 & 37 & 0.0054 \\
\cline { 2 - 8 } & Noon & 1539 & 6248,643 & 0.25 & 57.57 & 39 & 0.0051 \\
\hline
\end{tabular}

The alternative is to change the geometry of the approach at the intersection. Keep in mind that after calculating the cycle time in optimal conditions, it turns out that the DS value at several intersections is still considered quite high. Therefore, the signal control solution does not meet the MKJI requirements.

\section{1) Spada Intersection}

At the Spada intersection, it is known that the highest average delay during peak morning hours is $354.51 \mathrm{sec} / \mathrm{pcu}$. If you trace on KM 14 of 2006 [3] that the average delay of that size is included in class F. From the results of the research above, the highest degree of saturation is 1.31 . Therefore, it is necessary to have traffic engineering to improve intersections with a better signal. Therefore, it is necessary to look for the $C_{\text {opimum }}$ value so that the degree of saturation of each approach is the same as the existing theory and the intersection performance results are presented in Table 5. 
Table 5. Value of DS with Optimum Cycle Time at the Spada Junction

\begin{tabular}{|c|c|c|}
\hline $\begin{array}{l}\text { Period } \\
\text { Time }\end{array}$ & $\begin{array}{l}\text { Optimum } \\
\text { Mean } \\
\text { Deviation } \\
\text { Delay } \\
\text { ( } \mathrm{sec} / \mathrm{pcu})\end{array}$ & $\begin{array}{c}\text { Optimum } \\
\text { Service Level } \\
\text { (LoS) }\end{array}$ \\
\hline Morning & 48.55 & $\mathrm{E}$ \\
\hline Noon & 62.01 & $\mathrm{~F}$ \\
\hline Non Peak & 44.41 & $\mathrm{E}$ \\
\hline
\end{tabular}

After engineering the change in the signal time value, the highest degree of saturation is 0.9. In addition, the change in the degree of saturation also affects the average delay value, which is $48.55 \mathrm{sec} /$ junior high school and is included in the E service class at the peak of the morning. Changes in the degree of saturation also have an effect on the average delay value, which is $62.01 \mathrm{sec} /$ junior high school and is included in the $\mathrm{F}$ service class during the peak hours of the day. obtained the DS count of 0.86 . Meanwhile, the average delay of intersection is $44.41 \mathrm{sec} / \mathrm{pcu}$ and is included in the E category.

\section{2) Bhayangkara Intersection}

At the peak hour of the day, it is necessary to calculate traffic engineering, because the average delay is $306.37 \mathrm{sec} / \mathrm{pcu}$ which according to KM 14 of 2006 [3] is included in the service class $\mathrm{F}$ and the highest degree of saturation is 1.34 and after calculating the optimum cycle time is obtained. the results are as in Table 6.

Table 6. DS Value with Optimal Cycle Time at the Bhayangkara Simpang

\begin{tabular}{ccc}
\hline Period & $\begin{array}{c}\text { Optimum } \\
\text { Mean } \\
\text { Dime } \\
\text { Deviation } \\
\text { Delay } \\
(\mathrm{sec} / \mathrm{pcu})\end{array}$ & $\begin{array}{c}\text { Level of } \\
\text { Service } \\
(\mathrm{LoS})\end{array}$ \\
\hline Morning & 180.92 & $\mathrm{~F}$ \\
\hline Noon & 73.47 & $\mathrm{~F}$ \\
\hline Non Peak & - & - \\
\hline
\end{tabular}

With the change in the timing of the green signal according to the calculations above, the degree of saturation of each approach to the intersection changes. From the average value of the degree of saturation that actually reaches $>1$, after engineering changes in the signal time value, the highest degree of saturation is 0.88. In addition, changes in the degree of saturation also have an effect on the average delay value, which is $16.37 \mathrm{sec} /$ junior high school and is included in service class $\mathrm{C}$ at the peak hours of the day.

\section{3) Jarwo Intersection}

At the Bhayangkara intersection, it is known that the highest average delay during peak morning hours is $594.8 \mathrm{sec} / \mathrm{pcu}$. If you trace the KM 14 Year 2006 [3] that the average delay of that size is included in class F. From the research results above, the highest degree of saturation value is 1.53 . At the peak hour of the day it is known that the highest average delay at the peak of the morning is $301.28 \mathrm{sec} /$ pcu. If the trace on the KM 14 of 2006 that the average delay for the incoming class F. From the above results, obtained the highest degree of saturation value of 1.3 and after the optimum cycle time calculation results obtained in Table 7.

Table 7. DS value with Cycle Time Optimum in Simpang Jarwo

\begin{tabular}{|c|c|c|}
\hline $\begin{array}{l}\text { Period } \\
\text { Time }\end{array}$ & $\begin{array}{l}\text { Optimum } \\
\text { Mean } \\
\text { Deviation } \\
\text { Delay } \\
\text { (sec/pcu) }\end{array}$ & $\begin{array}{c}\text { Level of } \\
\text { Service } \\
(\mathrm{LoS})\end{array}$ \\
\hline Morning & 180,92 & $\mathrm{~F}$ \\
\hline Noon & 73,47 & F \\
\hline Non Peak & - & - \\
\hline
\end{tabular}

With the change in the timing of the green signal according to the calculations above, the degree of saturation of each approach to the intersection changes. From the average value of the degree of saturation that actually reaches> 1 , after engineering changes to the signal time value, the highest degree of saturation is 0.97 at the peak of the 
morning. After engineering changes to the signal time value, the highest degree of saturation is 0.92 . In addition, changes in the degree of saturation also have an effect on the average delay value, which is $73.63 \mathrm{sec} /$ junior high school and is included in the $\mathrm{F}$ service class during the peak hours of the day. At non-peak hours, the change in the degree of saturation also affects the average delay value, which is $39.57 \mathrm{sec} /$ junior high school and is included in the service class D.

\section{4) Mastrip Intersection}

At the peak hours of the morning, it is known that the highest average delay at the peak hours of the morning is $305.91 \mathrm{sec} / \mathrm{smp}$. If you trace on KM 14 of 2006 that the average delay of that size is included in class $\mathrm{F}$ and requires traffic engineering. Meanwhile, the peak hours of the day have an average delay of $58.52 \mathrm{sec} /$ junior high school which according to KM 14 of 2006 [3] is included in service class $\mathrm{E}$ and the highest degree of saturation is 0.95 . The calculation is also carried out at non-peak hours with an average vehicle volume or a vehicle volume that is not high at the Mastrip Junction, explained according to Table 8 .

Table 8. DS Value with Optimum Cycle Time at Simpang Mastrip

\begin{tabular}{|c|c|c|}
\hline $\begin{array}{l}\text { Period } \\
\text { Time }\end{array}$ & $\begin{array}{l}\text { Optimum } \\
\text { Mean } \\
\text { Deviation } \\
\text { Delay } \\
\text { (sec/pcu) }\end{array}$ & $\begin{array}{c}\text { Level of } \\
\text { Service } \\
\text { (LoS) }\end{array}$ \\
\hline Morning & 164,02 & $\mathrm{~F}$ \\
\hline Noon & 39,87 & D \\
\hline Non Peak & 39,36 & D \\
\hline
\end{tabular}

From the calculation of the optimum cycle time, a new signal value is obtained to allow changing the existing degree of saturation. With the change in the timing of the green signal according to the calculations above, the degree of saturation of each approach to the intersection changes. From the average value of the degree of saturation that actually reaches $>1$, after engineering changes to the signal time value, the highest degree of saturation is 0.96. In addition, changes in the degree of saturation also have an effect on the average delay value, which is $164.02 \mathrm{sec} /$ junior high school and is included in the $\mathrm{F}$ service class during peak morning hours. Changes in the degree of saturation also have an effect on the average delay value, which is $39.87 \mathrm{sec} /$ junior high school and entered into service class D at the peak hours of the day. At non-peak hours after engineering changes in the signal time value, the highest degree of saturation is 0.76 . In addition, the change in the degree of saturation also affects the average delay value, which is $39.36 \mathrm{sec} /$ junior high school and is included in the service class D.

\section{CONCLUSIONS AND SUGGESTIONS \\ 4.1 Conclusions}

From the data analysis and discussion, the following conclusions can be drawn:

1. The performance of sections and intersections in the Pagah area does not meet the appropriate service class. This is due to the significant growth of vehicles each year.

2. After calculating the optimum cycle time at the Spada intersection, Bhayangkara intersection, Jarwo intersection and Mastrip intersection, the performance of the four intersections became better.

\subsection{Suggestions}

From the conclusions outlined above, there are several suggestions that can be proposed, namely:

1. Further research is needed in the Pagah area which is closer to the conditions in the field.

2. Seeing the large volume of vehicles at the intersection, it is necessary to do other engineering so that there is no further delay

\section{ACKNOWLEDGMENTS}

Thank you to all leaders of the Faculty of Engineering, Universitas Brawijaya, all leaders of the Department of Civil Engineering, Faculty of Engineering, Universitas Brawijaya. First supervisor, Ir. Achmad Wicaksono, M.Eng., Ph.D. and Prof. Ir. Ludfi Djakfar, MSCE, Ph.D as the second supervisor. The Jember Regency Government has provided data and information so that the writing of this research can be carried out. Fellow students majoring in Civil 
Engineering and all parties who have provided assistance and support for this research.

\section{REFERENCES}

[1] Jember Regency Statistics Agency. [Online] Available at:
[2] https://jemberkab.bps.go.id

[3] Directorate General of Highways. 1997. Indonesian Road Capacity Manual . Jakarta. Public

Works 